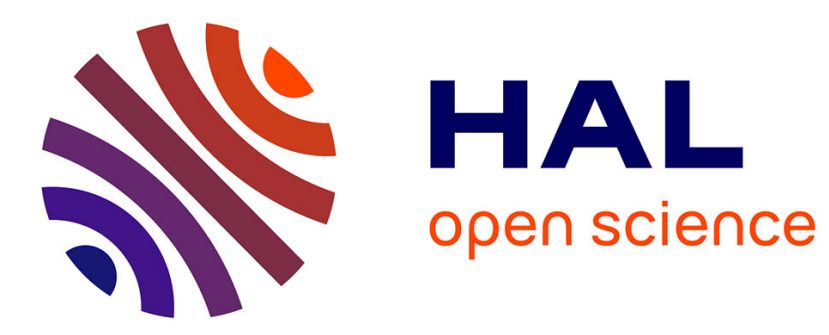

\title{
Temporal variability in soil hydraulic properties under drip irrigation
}

I. Mubarak, J.C. Mailhol, Rafaël Angulo-Jaramillo, P. Ruelle, Pierre Boivin, M.R. Khaledian

\section{- To cite this version:}

I. Mubarak, J.C. Mailhol, Rafaël Angulo-Jaramillo, P. Ruelle, Pierre Boivin, et al.. Temporal variability in soil hydraulic properties under drip irrigation. Geoderma, 2009, 150, p. 158 - p. 165. 10.1016/j.geoderma.2009.01.022 . hal-00547590

\author{
HAL Id: hal-00547590 \\ https://hal.science/hal-00547590
}

Submitted on 16 Dec 2010

HAL is a multi-disciplinary open access archive for the deposit and dissemination of scientific research documents, whether they are published or not. The documents may come from teaching and research institutions in France or abroad, or from public or private research centers.
L'archive ouverte pluridisciplinaire HAL, est destinée au dépôt et à la diffusion de documents scientifiques de niveau recherche, publiés ou non, émanant des établissements d'enseignement et de recherche français ou étrangers, des laboratoires publics ou privés. 
Geoderma, Volume 150, Issues 1-2, 15 April 2009, Pages 158-165

Author-produced version of the final draft post-reefering article.

Orginal version available at Elsevier B.V. doi:10.1016/i.geoderma.2009.01.022

4

Temporal variability in soil hydraulic properties under drip irrigation

Ibrahim Mubarak ${ }^{1,2,3 *}$, JeAn Claude Mailhol ${ }^{2}$, RAFAel Angulo-JARAmillo ${ }^{1,4}$, Pierre Ruelle ${ }^{2}$, Pascal Boivin ${ }^{5}$, MOHAMMADREZA KHALEDIAN ${ }^{2,6}$

${ }^{I}$ Laboratoire d'étude des Transferts en Hydrologie et Environnement, LTHE (UMR 5564, CNRS, INPG, UJF, IRD), BP 53, 38041, Grenoble, Cedex 9, France.

${ }^{2}$ Cemagref, UMR G-eau, F-34096 Montpellier, France.

${ }^{3}$ AEC of Syria, Department of agriculture, PB 6091, Damascus, Syria.

${ }^{4}$ Laboratoire des Sciences de l'Environnement, LSE-ENTPE, Rue Maurice Audin, 69518 Vaulx en Vélin, France.

${ }^{5}$ Laboratoire Sols et Substrats à l'EIL, University of Applied Sciences of Western Switzerland

${ }^{6}$ Guilan University of Iran. 
ABSTRACT

Predicting soil hydraulic properties and understanding their temporal variability during the irrigated cropping season are required to mitigate agro-environmental risks. This paper reports field measurements of soil hydraulic properties under two drip irrigation treatments, full (FT) and limited (LT). The objective was to identify the temporal variability of the hydraulic properties of field soil under high-frequency water application during a maize cropping season. Soil hydraulics were characterized using the Beerkan infiltration method. Seven sets of infiltration measurements were taken for each irrigation treatment during the cropping season between June and September 2007. The first set was measured two weeks before the first irrigation event. The results demonstrated that both soil porosity and hydraulic properties changed over time. These temporal changes occurred in two distinct stages. The first stage lasted from the first irrigation event until the root system was well established. During this stage, soil porosity was significantly affected by the first irrigation event, resulting in a decrease in both the saturated hydraulic conductivity $K_{s}$ and the mean pore effective radius $\xi_{m}$ and in an increase in capillary length $\alpha_{h}$. These hydraulic parameters reached their extreme values at the end of this stage. This behavior was explained by the "hydraulic" compaction of the surface soil following irrigation. During the second stage, there was a gradual increase in both $K_{s}$ and $\xi_{m}$ and a gradual decrease in $\alpha_{h}$ when the effect of irrigation was overtaken by other phenomena. The latter was put down to the effects of wetting and drying cycles, soil biological activity and the effects of the root system, which could be asymmetric as a result of irrigation with only one drip line installed for every two plant rows.

The processes that affected soil hydraulic properties in the two irrigation treatments were similar. No significant change in $\xi_{m}$ and $\alpha_{h}$ was observed between FT and LT. However, as a result of daily wetting and drying cycles, which were strongest in LT, the soil in this treatment was found to be more conductive than that of FT. This showed that most of the changes in pore-size distribution occurred in the larger fraction of pores.

The impact of these temporal changes on the dimensions of the wetting bulb was studied using a simplified modeling approach. Our results showed that there were marked differences in the computed width and depth of wetting bulb when model input parameters measured before and after irrigation were used. A temporal increase in capillary length led to a more horizontally elongated wetting bulb. This could improve both watering and fertilization of the root zone and reduce losses due to deep percolation. As a practical result of this study, in order to mitigate agro-environmental risks we recommend applying fertilizers after the restructuration of tilled soil. Further studies using improved models accounting for temporal changes in soil hydraulic properties are needed. 
Drip irrigation has become quite common thanks to its great potential to use less water and to localize chemical applications, thereby enhancing the efficiency of irrigation and fertilization and reducing the risk of pollution. However, these objectives can only be achieved if the irrigation system is correctly designed (e.g. emitter discharge rate, emitter spacing, tape lateral spacing, diameter and length of the lateral system) and well managed (e.g. irrigation scheduling and fertilization strategy) for any given set of soil, crop and climatic conditions.

In contrast to surface or sprinkler systems, the frequency of the water application under drip irrigation is high. This means the infiltration period is a very important stage of the irrigation cycle (Rawlins, 1973). A good knowledge of the soil hydraulic properties involved in the multidirectional infiltration process during the course of this cycle is required to optimize water applications. The ability to estimate the dimensions of the wetting bulb i.e., water extending laterally and vertically away from an emitter is an important criterion for the design of drip systems to ensure efficient irrigation and to avoid the movement of water beyond the root zone (Bresler, 1978; Zur et al., 1994; Zur, 1996 and Revol et al., 1997). Because analytical models provide a rapid way of determining the position of the wetting front (Revol et al., 1997; Cook et al., 2003; Thorburn et al., 2003), researchers have tried to develop a simple model to describe the soil wetting pattern with micro-irrigation systems. Schwartzman and Zur (1986) developed a simplified semi-empirical model of wetted soil geometry with surface trickle irrigation, which depends on specific parameters i.e., soil type (saturated hydraulic conductivity), emitter discharge per unit length of laterals, and total amount of water in the soil. Al-Qinna and Abu-Awwad (2001) estimated an exponential function with a water application rate to describe the horizontal width and the vertical depth of the advance of the wetting front. In their field study, Revol et al. (1997) found that the infiltration solutions of Philip (1984) provided good estimations of the radial (r) and vertical (z) distance of the wetted zone from the water sources. Warrick (2003) reviewed many analytical solutions describing water infiltration from point and line sources.

In a particular soil-water-plant system and climatic conditions, the transport properties of the soil surface layer can change during the growing season. This temporal variation is likely due to modifications in surface soil conditions resulting from tillage practices (Mohanty et al., 1996; Cameira et al., 2003), and to the effects of the rooting system (Shirmohammadi and Skaggs, 1984; Rasse et al., 2000 and Iqbal et al., 2005). Wetting and drying cycles and the irrigation system can also alter the soil structure. Hydrodynamic behavior is consequently affected primarily by the current state of the soil structure, as well as its texture (Mapa et al., 1986; Messing and Jarvis, 1993; Angulo-Jaramillo et al., 1997; Cameira et al., 2003; Mailhol et al., 2005). However, the above-mentioned studies dealt with traditional irrigation systems that supply large amounts of water to the soil system at low frequencies. Only Mapa et al. (1986) addressed the effects on soil hydraulics of the wetting and drying cycles caused by drip irrigation following tillage. These authors found that soil hydraulic properties changed significantly after only one wetting/drying cycle in a silty clay loam and in a clay loam. However, in their study, each wetting/drying cycle included wetting (18 h of irrigation) followed by drying (7-10 days). In our opinion, this irrigation schedule thus more resembled that of traditional irrigation systems. To our knowledge, no study has tried to identify temporal variations in soil hydraulic properties during a cropping season under highfrequency water application.

The objectives of the present study were (i) to characterize temporal variability of soil hydraulic properties due to changes in soil structure under high-frequency drip irrigation, using the Beerkan infiltration method, and (ii) to illustrate the effects of temporal variability 
1 on the geometry of the wetting pattern generated by emitters, i.e., radius and depth, using the 2 infiltration solution of Philip (1984). 


\section{Experimental Site, Soil and Agricultural Practices}

Field experiments were conducted on a loamy soil containing an average of $43 \%$ sand, $40 \%$ silt and $17 \%$ clay in the plowed layer with a relatively small coefficient of variation. The experimental field is located at the Cemagref Experimental Station in Montpellier, France $\left(43^{\circ} 40^{\prime} \mathrm{N}, 3^{\circ} 50^{\prime} \mathrm{E}\right)$ where there is a fully equipped meteorological station. In the 2006-2007 cultivation years, the field was plowed to a depth of $35 \mathrm{~cm}$ on November 15 with a moldboard plow. The seed bed (top $8 \mathrm{~cm}$ ) was prepared in April with a rotary harrow to fragment the soil.

On April 24, maize (Pionner PR35Y65) was sown with a row spacing of $0.75 \mathrm{~m}$ and at a plant density of $100000 \mathrm{ha}^{-1}$. Water was delivered through a line drip irrigation system with an emitter spacing of $30 \mathrm{~cm}$ and a flow rate of $3.67 \mathrm{~L} \mathrm{~h}^{-1} \mathrm{~m}^{-1}$. One drip line was installed for every two plant rows leading to a lateral spacing of $1.5 \mathrm{~m}$. Two different irrigation treatments, i.e. a full treatment (FT) and a limited treatment (LT), were investigated. On the basis of estimated crop water demand, irrigation was applied daily for three hours in FT. As it was not possible to irrigate during weekends, supplementary irrigation of three hours were applied on Fridays and Mondays. This irrigation schedule was maintained until the last week of July, after which irrigation was reduced to two hours per day with no supplementary irrigation at weekends. In LT, irrigation water was applied for three hours every other day (only on three days per week) until the end of the irrigation season. In both treatments, the crop was first irrigated for approximately $7.5 \mathrm{hr}$ on June 19 to maintain the wetting bulb throughout the cropping season.

Potential crop evapotranspiration ETc was calculated from the daily reference evapotranspiration (Allen et al., 1998) and the crop coefficient Kc (Doorenbos and Pruit, 1977). The maximum value of Kc was 1.2. Figure 1 shows crop water demand and water inputs from rainfall and irrigation over the cropping season. The cumulative amount of irrigation water applied in FT was approximately equal to estimated ETc except at the end of irrigation season due to a breakdown in the pumping station. The cumulative irrigation amount applied in FT was $430 \mathrm{~mm}$. In LT, the total water amount was $300 \mathrm{~mm}$, i.e. approximately $60 \%$ of estimated crop evapotranspiration.

\section{Infiltration Measurements and Data Collection}

The Beerkan infiltration method, (a 3D axi-symmetric infiltration method) was used with a simple annular ring (Haverkamp et al., 1996; Lassabatère et al., 2006). Seven sets of infiltration measurements were performed during the cropping season. Major variations in soil structure correspond to the reorganization of soil particles following the first irrigation event (Mapa et al., 1986; Mailhol et al., 2005). For this reason, in the present study we tried to characterize the soil following the first irrigation event in detail. Measurements were taken two weeks before irrigation started, five days after the $1^{\text {st }}$ irrigation event, one week later, one week later around the time the root system reached maximum, one month later, two weeks later, and just prior to harvest.

At each measurement date, six to eight infiltration tests were performed on a preselected plot in the center of each treatment area. Each plot was $4.5 \times 4.5 \mathrm{~m}^{2}$ square and included three adjacent drip lines. Infiltration tests were performed under the irrigation pipelines midway between irrigated plant rows, and spaced $1.5 \mathrm{~m}$ apart.

Infiltration tests were performed using a $65 \mathrm{~mm}$-radius cylinder inserted to a depth of about $1 \mathrm{~cm}$ to avoid lateral water losses. A fixed volume of water $(100 \mathrm{ml})$ was poured into the cylinder at time zero, and the time needed for the infiltration of the known volume of water was measured. When the first volume had completely infiltrated, a second known volume of 
water was added to the cylinder, and the time needed for it to infiltrate was added to the previous time. This procedure was repeated until apparent steady state was reached, i.e. until two consecutive infiltration times were identical, and the cumulative infiltration was then recorded (Lassabatère et al., 2006). In addition, before the infiltration test, a soil sample was extracted in the vicinity of the infiltration ring to determine the initial soil gravimetric water content and particle-size distribution $(<2 \mathrm{~mm})$, the latter being analyzed using the sedimentation method. Another $200 \mathrm{~cm}^{3}$ sample was taken to measure dry bulk density $\left(\rho_{\mathrm{d}}\right)$. Saturated volumetric water content $\left(\theta_{\mathrm{s}}\right)$ was calculated as total soil porosity considering the density of the solid particles to be $2.65 \mathrm{~g} \mathrm{~cm}^{-3}$.

\section{Soil Hydraulic Characterization and Data Analysis}

The BEST algorithm (Beerkan Estimation of Soil Transfer parameters) (Lassabatère et al., 2006) was used to determine soil hydraulic properties. This specific algorithm determines characteristic hydraulic curves that take into account the van Genuchten equation for the water retention curve, $h(\theta)$, (Eq. 1a) with the Burdine condition (Eq. 1b) and the Brooks and Corey relation (Eq. 2) for hydraulic conductivity curve, $K(\theta)$, (Burdine, 1953; Brooks and Corey, 1964; van Genuchten, 1980) :

$$
m=1-\frac{2}{n}
$$

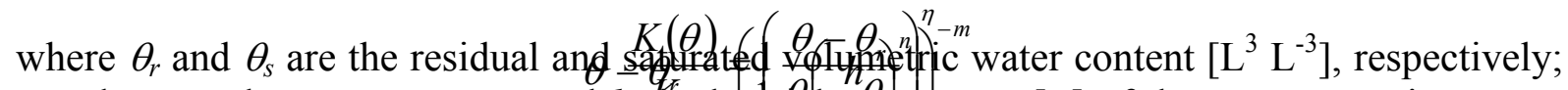

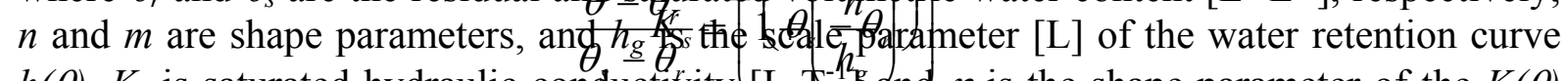
$h(\theta), K_{s}$ is saturated hydraulic conductivity [L $\left.\mathrm{T}^{-1}\right]$ and $\eta$ is the shape parameter of the $K(\theta)$ relationship. $\theta_{r}$ is usually very low and was thus considered to be zero. $\theta_{s}$ was calculated as total soil porosity considering the density of the solid particles to be $2.65 \mathrm{~g} \mathrm{~cm}^{-3}$. The hydraulic properties were thus represented using five parameters: $\theta_{s}, n, h_{g}, K_{s}, \eta$. Following Haverkamp et al. (1996), the shape parameters $n$ and $\eta$ were assumed to mainly depend on soil texture, while $\theta_{s}, h_{g}$ and $K_{s}$ were assumed to mainly depend on soil structure.

The BEST algorithm estimates the shape parameters from particle-size distribution by classical pedotransfer functions. BEST derives saturated hydraulic conductivity and sorptivity $\mathrm{S}\left(\mathrm{L} \mathrm{T}^{-0.5}\right)$ by modeling the 3D infiltrations performed at zero water pressure head (i.e. Beerkan infiltration method). The 3D cumulative infiltration $I(t)$ and the infiltration rate $q(t)$ can be approached by the explicit transient two-term and steady-state equations given by Haverkamp et al. (1994). The reader is referred to the study of Lassabatère et al. (2006) for more details on fitting experimental data on infiltration on analytical expressions that can provide estimations of scale parameters. Lassabatère et al. (2006) also described the main characteristics of the BEST algorithm which is coded with MathCAD 11 (Mathsoft Engineering and Education, 2002).

The capillary length $\left(\alpha_{h}\right)$ was then estimated from sorptivity $(\mathrm{S})$ and the other hydraulic parameters through (Haverkamp et al., 2006):

$$
\alpha_{h}=\frac{S^{2}}{c_{p}\left(\theta_{s}-\theta_{0}\right)\left[1-\left(\frac{\theta_{0}}{\theta_{s}}\right)^{\eta}\right] K_{s}}
$$


where $\theta_{0}$ is initial water content and $c_{p}$ is a function of the shape parameters for the van Genuchten (1980) water retention equation (see Haverkamp et al., 2006 and Lassabatère et al., 2006). The relationship between the capillary length and the characteristic microscopic pore "radius" i.e., the mean characteristic dimension of hydraulically functional pore, $\xi_{m}$, is known to be:

$$
\xi_{m}=\frac{\sigma}{g \rho \alpha_{1}}
$$

7 where $\sigma$ is the surface tension $\left[\mathrm{MT}^{-2}\right], \rho_{w}$ is the density of water $\left[\mathrm{ML}^{-3}\right]$ and $g$ is the gravitational acceleration $\left[\mathrm{LT}^{-2}\right]$. Taking the properties of pure water at $20^{\circ} \mathrm{C}$ as appropriate, Equation (4) reduces to

where $\alpha_{h}$ and $\xi_{m}$ are expressed in $\mathrm{mm}$.

$$
\xi_{m}=\frac{7.44}{\alpha_{h}}
$$

Standard statistical analysis was used in this study. In both treatments, the Kolgomorov-Smirnov test was used to check the assumption of normality of the data sets. The effects of time on each soil structure parameter, $K_{s}, \alpha_{h}, \xi_{m}$ and the comparison between the two treatments, FT and LT, were evaluated by analysis of significance using the $t$-test at 0.05 probability level.

\section{Determining the Horizontal and Vertical Components of the Wetting Front}

The analytical simulation model developed by Philip (1984) was used to estimate the surface radius $(r)$ and the depth $(z)$ of the wetted soil volume. Because this model relies on assumptions such as the homogeneity of soil hydraulic properties, we used it as indicative rather than perspective. Philip (1984) found that the travel time of the wetting front away from a point source radially and vertically is given for dimensionless time $(T)$, vertical distance $(Z)$ and radial distance $(R)$ as:

and

$$
T=\frac{Z^{2}}{2}-Z+\ln (1+Z)
$$

where

$$
T=2 \exp \left[R-R^{2}+\frac{R^{3}}{2}\right]-2
$$

$$
\begin{gathered}
T=\frac{q t}{16 \pi \Delta \theta \alpha_{h}^{3}} \\
z=2 \alpha_{h} Z \\
r=2 \alpha_{h} R
\end{gathered}
$$

where $q$ is the emitter flow rate, $t$ is time, $\alpha_{h}$ is the capillary length and $\Delta \theta$ is the difference between the average volumetric water content in the wetted soil and the initial volumetric water content. 


\section{Soil Hydraulic Properties}

Combining analysis of particle size distribution with modeling of the 3D infiltration experiments enabled us to fully determine the hydraulic parameters of the water retention and unsaturated hydraulic conductivity curves. Table 1 summarizes the statistical parameters of data sets of physical and hydraulic parameters.

The shape parameters of $h(\theta)$ and $K(\theta)$ varied little over time. This low variability is consistent with the assumption that the shape parameters mainly depend on soil texture (Haverkamp et al., 1996).

The $K_{s}, \alpha_{h}$, and $\xi_{m}$ data sets were consistent with a log normal distribution (Kolgomorov-Smirnov test). Similar results were reported in studies of soil hydraulic properties (Mulla and McBratney 2002). Statistical analysis was thus performed on logtransformed values. At almost every measurement date, $K_{s}$ showed the highest variability with coefficients of variation (CV), ranging from $11 \%$ to $43 \%$. The data sets of both $\xi_{m}$ and $\alpha_{h}$ showed low CV values ranging from about $14 \%$ to $24 \%$ over the whole measurement period. This confirms the homogeneity of soil preparation, the precision of the Beerkan infiltration method, and low spatial variability at small scales.

Figures 2, 3 and 4 show the values of $K_{s}, \alpha_{h}$, and , $\xi_{m}$ obtained during the cropping season in the two treatments, FT and LT, as a function of time and as a function of cumulative water application depth. Each graph can be divided into two separate stages. The first stage lasted from the first irrigation event until July 10 around the time the root system was well established. The second stage lasted until the end of the cropping season. During the $1^{\text {st }}$ stage, hydraulic properties were significantly affected by the first irrigation event (according to the $t$ test) (Table 2). The hydraulic parameters reached their extreme values at the end of this stage. In FT, the mean value of $K_{s}$ decreased sharply over time and with cumulative water application depth. Its value dropped from $8.5 \times 10^{-3} \mathrm{~mm} \mathrm{~s}^{-1}$ to $1.6 \times 10^{-3} \mathrm{~mm} \mathrm{~s}^{-1}$ at the end of this stage. It subsequently increased gradually during the second stage to reach a mean value of $5.3 \times 10^{-3} \mathrm{~mm} \mathrm{~s}^{-1}$ just prior to harvest (Fig. 2 and Table 3 ). In LT, $K_{s}$ reached its minimal value $\left(3.3 \times 10^{-3} \mathrm{~mm} \mathrm{~s}^{-1}\right)$ only five days after the beginning of the irrigation season. Subsequently, the mean value of $K_{s}$ did not significantly vary, according to the $t$-test, for a period of some weeks before rising significantly again to reach $7.7 \times 10^{-3} \mathrm{~mm} \mathrm{~s}^{-1}$ at the end of the second stage (Fig. 2 and Table 3).

In both FT and LT, $\xi_{m}$ decreased from $0.14 \mathrm{~mm}$ just before the first irrigation event to about $0.06 \mathrm{~mm}$ at the end of the first stage. Subsequently, this parameter gradually increased to reach approximately $0.10 \mathrm{~mm}$ at the end of the second stage (Fig. 4 and Table 3 ). As the mean effective pore radius is inversely proportional to capillary length, the latter displayed inverse behavior with respect to $\xi_{m}$ (Fig. 3 and Table 3). It increased significantly from about $54 \mathrm{~mm}$ before the start of the irrigation season to a maximal value of $120 \mathrm{~mm}$ at the end of the first stage. It then decreased gradually to reach a value of about $72 \mathrm{~mm}$ just before harvest. The temporal variations in soil hydraulic properties were in agreement with the temporal change in dry bulk density during the cropping season. Dry bulk density showed a significant increase five days after irrigation started, and then stabilized somewhat before starting a downward trend at the end of the second stage (Fig. 5).

Temporal variations in soil hydraulic properties were, in general, similar in FT and LT but with different apparent response intensity (Figs 2, 3 and 4). In the second stage, $K_{s}$ values were significantly higher in LT than in FT, while in the first stage the values did not differ (according to the $t$-test) (Table 3). No significant differences were found in $\alpha_{h}$ and $\xi_{m}$ between the two treatments at each measurement date ( $t$-test) (Table 3). As a function of cumulative water application depth, FT showed that during the irrigation season, the three parameters 
reached their extreme values at the same cumulative water application depth of $144 \mathrm{~mm}$. This value was much higher than that in LT (81 mm) (Figs 2, 3 and 4).

In the two treatments, the temporal changes in $K_{s}$ were generally associated with changes in $\xi_{m}$ at all measurement dates and inversely to changes in both $\rho_{d}$ and $\alpha_{h}$. The mean characteristic pore dimension and the capillary length are actual estimates of the capillary component of water transfer into the soil. Thus, the higher $\xi_{m}$, the greater the effect of gravity compared to capillarity, as the infiltration driving force.

Temporal changes in the soil hydraulic properties can be commented as follows. At the beginning of the irrigation season, temporal variations in soil hydraulic properties could be due to the "hydraulic" compaction of soil following water application. This is in agreement with the concomitant increase in the dry bulk density (Fig. 5 and Table 1). The volume of water delivered during the first irrigation event and the following frequent irrigations caused restructuration of the fragile structural porosity created by soil preparation operations (Mapa et al., 1986; Angulo-Jaramillo et al., 1997; Cameira et al. 2003). During the second part of the irrigation season, when the irrigation rate decreased due to lower water requirements, the effect of irrigation was overtaken by the effects of wetting and drying cycles associated with the effects of the rooting system. The rooting system could be asymmetric as a result of irrigation with one drip line installed for every two plant rows. Some roots could grow and develop preferentially in the vicinity of emitters, creating new channels or continuity between existing pores. Shirmohammadi and Skaggs (1984) observed that in cropped soils, hydraulic conductivity was much higher than in bare soils due to the effect of the rooting system. Similar results were also reported by Cameira et al. (2003), Iqbal et al. (2005) and Rasse et al. (2000). The latter authors found that the crop rooting system tended to increase water flow resulting in higher $K_{s}$ values and a larger macroporosity. In addition, as both $\alpha_{h}$ and $\xi_{m}$ are characteristic microscopic lengths estimating the capillary component of water transfer, their temporal variations indicated a change in structure of the fine soil fraction. An increase in $\alpha_{h}$ and a decrease in $\xi_{m}$ during the first stage indicates that the structural pattern of the fine fraction of soil changed from a poorly connected porous network before irrigation started to a more interconnected network in the middle of irrigation season. The presence of connected pores in that period may be the result of soil biological activity that is locally stimulated by the permanent high humidity of the wetted zone of the soil. White and Sully (1987) linked the higher value of the mean characteristic pore dimension to soil biological activity which is expected to be maximum in the surface soil layer. In addition, during the first stage, the change in these two parameters indicates a decrease in soil porosity leading to an increase in dry bulk density (Fig. 5). The reverse occurred during the second stage, confirmed by an increase in soil porosity at the end of irrigation season, and by a change in structural porosity from an interconnected porous network to a less connected one (Angulo-Jaramillo et al., 1997).

The processes affecting soil hydraulic properties were similar in the two irrigation treatments. Variations in $\alpha_{h}$ and $\xi_{m}$ over time were similar in FT and LT. Although we used two different irrigation schedules i.e., two different water amounts with two different application frequencies, the two microscopic lengths reached their extreme values at the same date i.e., at the end of the first stage, but not at the same cumulated water application depth. In our soil and climatic context, an added cumulated water application depth of from $81 \mathrm{~mm}$ to $144 \mathrm{~mm}$ did not lead to a significant change in the mean values of these two parameters. This indicates that both irrigation management systems play similar roles in the soil matrix. In other words, a change in irrigation management does not appear to adversely influence the fine fraction of the soil.

In contrast, $K_{s}$ values were significantly higher in LT than in FT during the second stage (Fig. 2 and Table 3). In LT, the soil was thus more conductive than in FT. This can be 
attributed to irrigation management. The frequency of water application used in LT (every other day) increased the importance of the alternating daily effects of wetting and drying cycles leading to the formation of the moderate cracks on the soil surface observed with this treatment during measurement campaigns. Thus, we can hypothesize that structural porosity is responsible for the largest water transport fraction (Cameira et al., 2003). This shows that different irrigation management systems mainly affect the larger fraction of pores. This confirms the effects of irrigation, the alternative cycles of wetting and drying, biological activity, root development on soil porosity.

The concomitance of extreme values of soil hydraulic properties in the two treatments may be due to the fact that these hydraulic properties are related to the same internal pore geometry. The difference between the two treatments in the cumulated water application depth at which our three hydraulic parameters reached their extreme values can be explained by the different volumes of water applied and by the irrigation schedule that stimulated or not the development of structural porosity in the surface soil layer.

\section{Effect of Temporal Changes on Simulated Components of the Wetting Front}

Based on the temporal changes in measured soil hydraulic parameters identified above, three sets of hydraulic properties were used to examine the effects of this phenomenon on the dimensions of the wetted soil volume. The first set represents the fragmented soil before irrigation started, so the initial values of soil hydraulic properties were used. The second set represents the restructuration of the soil some days after irrigation started and the average situation over the irrigation season. The third set represents the extreme situation of "hydraulic" compaction after three weeks of irrigation, that is to say at the $4^{\text {th }}$ measurement date (see Figs. 2, 3 and 4 from June 1 until July 8). The input parameters of the mathematical equations of Philip's model are (i) two given irrigation periods: $t=12 \mathrm{hr}$ and $24 \mathrm{hr}$ (ii) $\mathrm{q}=21$ $\mathrm{h}^{-1}$ as emitter flow rate, (iii) the difference $(\Delta \theta=0.2)$ between initial water content and mean value of water content of the wetted soil volume which are assumed to be uniform, and (iv) the mean value of capillary length for each hydraulic parameter set. Table 4 shows the width $(r)$ and depth $(z)$ of the wetting pattern computed from Eq. 6, 7 and 8 for the three sets and for the two irrigation periods. For the three parameter sets, it can be seen that the volume of wetted soil and of the water applied to the soil are similar. Results showed that there were differences in the dimensions of the wetting pattern. Initial soil hydraulic properties tended to form slightly vertically elongated bulb. The increase over time in the capillary length, i.e., characteristic of the capillary component of water transfer, led to an increase in the horizontal component of the wetting bulb (about 30\%) and to a decrease in its vertical component (about $25 \%$ ) for the two periods of irrigation concerned. In other words, it led to a horizontally elongated bulb. Differences in the dimensions were due only to temporal variability associated with water applications for the two given irrigation periods. 
In this study, the behavior of a loamy soil under drip irrigation was analyzed using the Beerkan infiltration method to identify the temporal variability of its hydraulic properties caused by high-frequency irrigation during a maize cropping season. Two different irrigation treatments, a full (FT) and a limited (LT), were investigated. Our results demonstrated that both soil porosity and hydraulic properties varied over time. Soil behavior can be divided into two separate stages. The first stage lasted from the first irrigation event (56 days after sowing of the crop) until the root system was well established (75 days after sowing). During this stage, soil porosity was significantly affected by the first irrigation event, resulting in a decrease in both saturated hydraulic conductivity $K_{s}$ and in the mean pore effective radius $\xi_{m}$, and in an increase in capillary length $\alpha_{h}$. These hydraulic parameters reached their extreme values at the end of this stage. This behavior was explained by the "hydraulic" compaction of the surface soil following irrigation.

Later in the season, during the second stage, a gradual increase in both $K_{s}$ and $\xi_{m}$ and a gradual decrease in $\alpha_{h}$ were observed in both FT and LT, when the effect of irrigation was overtaken by other phenomena. The latter was put down to the effects of wetting and drying cycles, soil biological activity, and the effect of the root system, which could be asymmetric as a result of irrigation with only one drip line installed for every two plant rows.

The processes that affect soil hydraulic properties in the two irrigation treatments were found to be similar. No significant change in mean effective pore radius and in capillary length was observed between FT and LT. However, as a result of daily wetting and drying cycles, which were very marked in LT, the soil was found to be more conductive than in the FT. This shows that different irrigation management systems mainly affect the larger fraction of pores i.e., structural pores.

Our work raises questions about the usefulness of taking this phenomenon into account to improve the efficiency of both water and fertilizer under drip irrigation. To answer this question, we studied the impact of temporal changes in soil hydraulic properties on the dimension of the wetting bulb using a simplified modeling approach. Our results demonstrated that there were major differences in the computed width and depth of the wetted bulb when model input parameters measured before and after irrigation were used. An increase in capillary length over time led to the more horizontally elongated bulb. This change can improve the efficiency of both irrigation and fertilization of the root zone and reduce losses of both water and solute due to deep percolation. As a practical result of this study, we recommend fertigation after the restructuration of tilled soil in order to mitigate agroenvironmental risks and to improve the efficiency of the use of solutes. The temporal changes in soil hydraulic properties identified in our study should be taken into account in future studies when simulating soil water transfer under drip irrigation in order to improve irrigation scheduling practices. 
3 The AEC of Syria is greatly acknowledged for the Ph.D. scholarship granted to Ibrahim 4 Mubarak. 


\section{REFERENCES}

Allen, R.G., Pereira, L.S., Raes, D. and Smith, M., 1998. Crop evapotranspiration: Guidelines for computing crop requirements. Irrigation and Drainage Paper No. 56, FAO, Rome, Italy, 300pp.

Al-Qinna, M.I., Abu-Awwad, A.M., 2001. Wetting patterns under trickle source in arid soils with surface crust. J. Agric. Eng. Res. 80(3): 301-305.

Angulo-Jaramillo, R., Moreno, F., Clothier, B.E., Thony, J.L., Vachaud, G., Fernandez-Boy, E. and Cayuela, J.A., 1997. Seasonal variation of hydraulic properties of soils measured using a tension disk infiltrometer. Soil Sci. Soc. Am. J. 61 (1): 27-32.

Bresler, E., 1978. Analysis of trickle irrigation with application to design problems. Irrig. Sci. 1:03-17.

Brooks, R.H. and Corey, C.T., 1964. Hydraulic properties of porous media. Hydrol. Paper 3., Colorado State University, Fort Collins.

Burdine, N.T., 1953. Relative permeability calculations from pore size distribution data. Petr. Trans. Am. Inst. Mining Metall. Eng. 198: 71-77.

Cameira, M. R., Fernando, R. M. and Pereira, L. S., 2003. Soil macropore dynamics affected by tillage and irrigation for a silty loam alluvial soil in southern Portugal. Soil Tillage Res. 70(2): 131-140.

Cook, F.J., Thorburn, P.J., Bristow, K.L., Cote, C.M., 2003. Infiltration from surface and buried point sources: the average wetting water content. Water Resour. Res. 39(12): 1364-1376.

Doorenbos, J. and Pruitt, W.O., 1977. Guidelines for predicting crop water requirements. Irrigation and Drainage Paper No. 24, $2^{\text {nd }}$ ed., FAO, Rome, 156pp.

Haverkamp, R., Ross, P.J., Smetten, K.R.J. and Parlange, J.Y., 1994. Three-dimensional analysis of infiltration from the disc infiltrometer. 2. Physically based infiltration equation. Water Resour. Res. 30: 2931-2935.

Haverkamp, R., Arrúe, J. L.,Vandervaere, J.P., Braud, I., Boulet, G., Laurent, J.P., Taha, A., Ross, P. J. and Angulo-Jaramillo, R., 1996. Hydrological and thermal behavior of the vadose zone in the area of Barrax and Tomelloso (Spain): experimental study, analysis and modeling. Project UE, No. EV5C-CT 920090.

Haverkamp, R., Debionne, S., Viallet, P., Angulo-Jaramillo, R. and de Condappa, D., 2006. Soil Properties and Moisture Movement in the Unsaturated Zone. In: J. W. Delleur (Editor), The handbook of Groundwater Engineering. CRC, pp. 6.1-6.59.

Iqbal, J., Thomasson, J.A., Jenkins, J.N., Owens, P.R. and Whisler, F.D., 2005. Spatial Variability Analysis of Soil Physical Properties of Alluvial Soils. Soil Sci. Soc. Am. J. 69: 1338-1350.

Lassabatère, L., Angulo-Jaramillo, R., Soria Ugalde, J. M., Cuenca, R., Braud, I. and Haverkamp, R., 2006. Beerkan Estimation of Soil Transfer parameters through infiltration experiments-BEST. Soil Sci. Soc. Am. J. 70: 521-532.

Mailhol, JC., Ruelle, P. and Popova, Z., 2005. Simulation of furrow irrigation practices (SOFIP): a field-scale modeling of water management and crop yield for furrow irrigation. Irrig Sci. 24: 37-48.

Mapa, R.B., Green, R.E. and Santo, L., 1986. Temporal variability of soil hydraulicproperties with wetting and drying subsequent to tillage. Soil Sci. Soc. Am. J. 50(5): $1133-1138$.

Mathsoft Engineering and Eduction, Inc., 2002. MathCad 11, Cambridge.

Messing, I. and Jarvis, N., 1993. Temporal variation in the hydraulic conductivity of a tilled clay soil as measured by tension infiltrometers. J. Soil Sci. 44: 11-24. 
Mohanty, B., Ankeny, M., Horton, R. and Kanwar, R., 1996. Spatial analysis of hydraulic conductivity measured using disk infiltrometers. Water Resour. Res. 30: 2489-2498.

Mulla, D. J. and McBratney, A. B., 2002. Soil spatial variability. In: M. E. Sumner (Editor), Handbook of Soil Science. CRC press, London, pp. A321-A352.

Philip, JR., 1984. Travel times from buried and surface infiltration point sources. Water Resour Res. 20: 990-994

Rasse, D.P., Smucker, A.J.M. and Santos, D., 2000. Alfalfa root and shoot mulching effects on soil hydraulic properties and aggregation. Soil Sci. Soc. Am. J. 64: 725-731.

Rawlins, S.L., 1973. Principals of managing high frequency irrigation. Soil Sci. Soc. Amer. Proc. 37: 626-629.

Revol, P., Clothier, B. E., Mailhol, J.C., Vachaud, G., and Vauclin, M., 1997. Infiltration from a Surface Point Source and Drip Irrigation 2. An Approximate Time-Dependent Solution for Wet-Front Position, Water Resour. Res. 33(8): 1869-1874.

Schwartzman, M., Zur, B., 1986. Emitter spacing and geometry of wetted soil volume. J. Irrig. Drain. Eng. 112(3): 242-253.

Shirmohammadi, A. and Skaggs, R., 1984. Effect of surface conditions on infiltration for shallow water table soils. Trans. ASAE. 27: 1780-1787.

Thorburn, P.J., Cook, F.J., Bristow, K.L., 2003. Soil-dependent wetting from trickle emitters: implications for trickle design and management. Irrig Sci. 22: 121-127.

van Genuchten, M.T., 1980. A closed form equation for predicting the hydraulic conductivity of unsaturated soils. Soil Sci. Soc. Am. J. 44: 892-898.

Warrick, A.W., 2003. Soil water dynamics. Oxford University Press, 391 pp.

White, I. and Sully, M.J., 1987. Macroscopic and microscopic capillary length and time scales from field infiltration. Water Resour. Res. 23: 1514-1522

Zur, B., 1996. Wetted soil volume as a design objective in trickle irrigation. Irrig Sci. 16:101105.

Zur, B., Ben-Hanan, U., Rimmer, A. and Yardeni, A., 1994. Control of irrigation amounts using velocity and position of wetting front. Irrig Sci. 14: 207-212. 


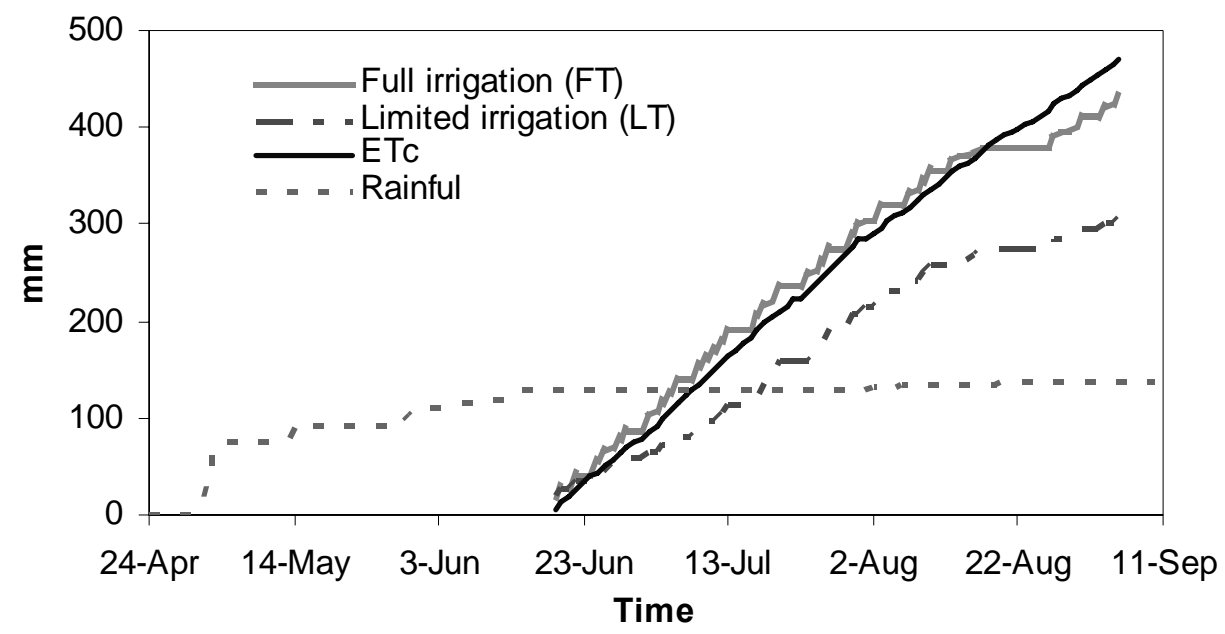

2 Fig. 1 Cumulative crop water use (ETc) and water inputs from rainfall and irrigation over crop season.
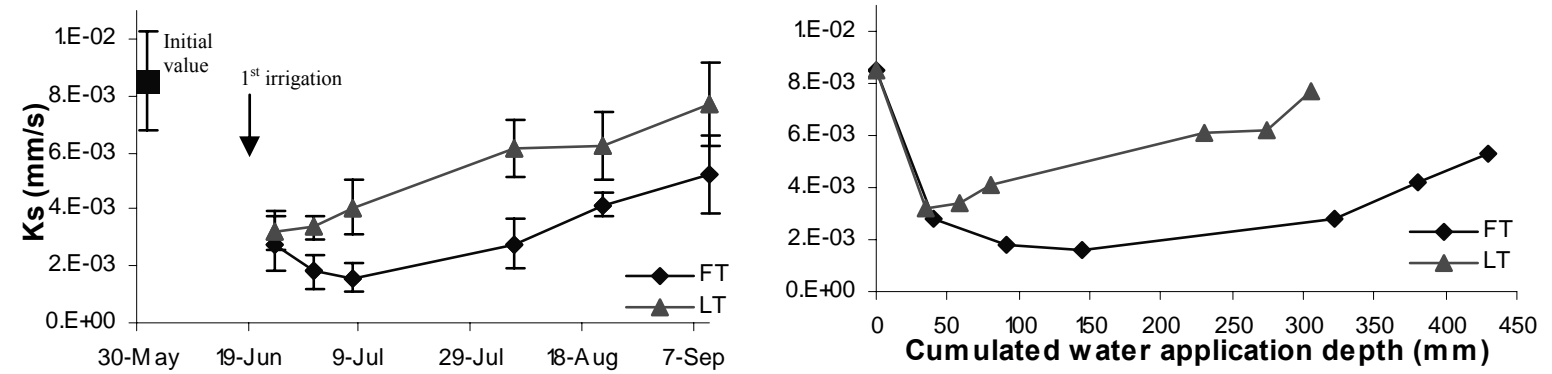

4 Fig. 2 Evolution of saturated conductivity (geometric mean with standard deviation) for both treatments

5 with time as well as with cumulative water application depth.
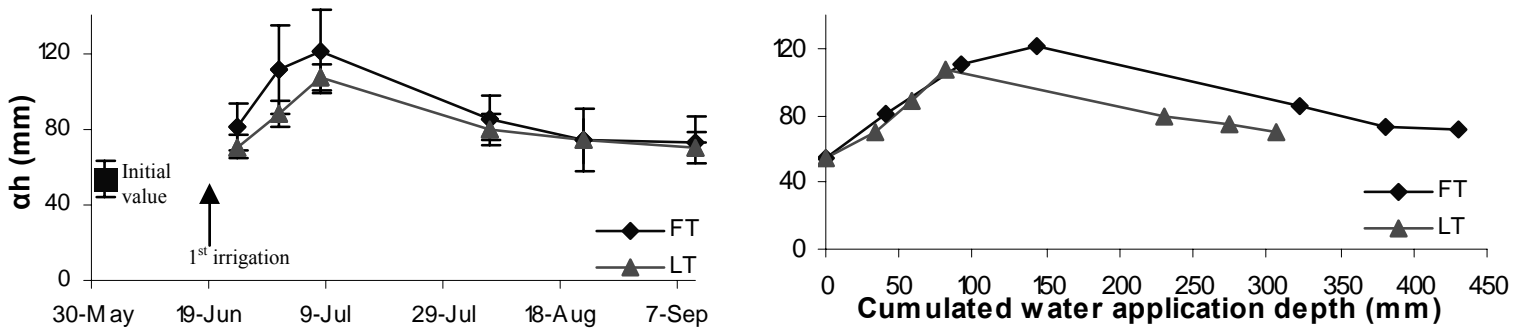

7 Fig. 3 Evolution of capillary length, $\alpha_{h}$, (geometric mean with standard deviation) for both treatments

8 with time as well as with cumulative water application depth. 

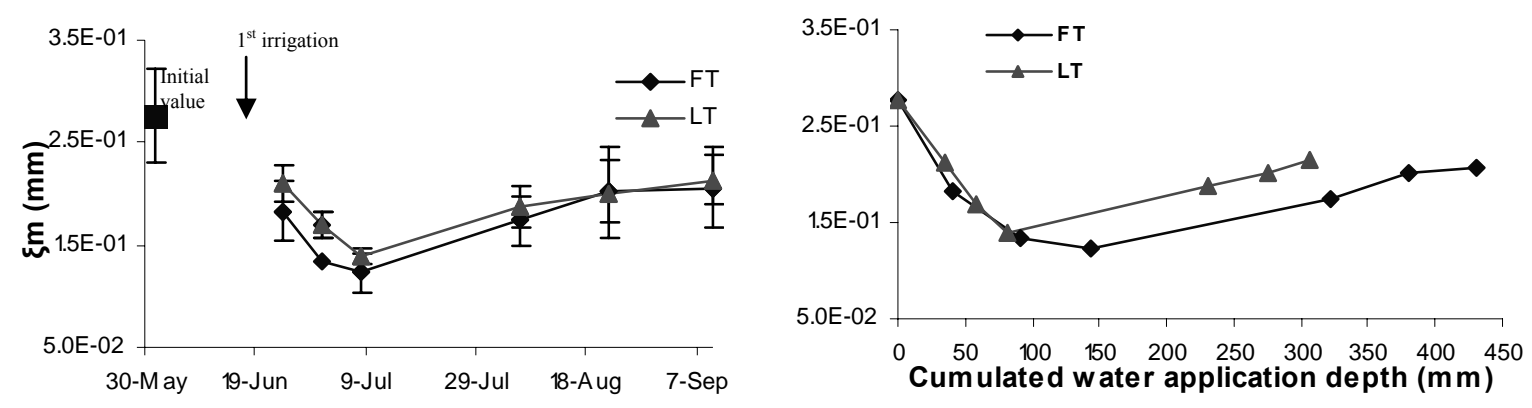

2 Fig. 4 Evolution of mean pore radius, $\xi_{\mathrm{m}}$, (geometric mean with standard deviation) for both treatments

3 with time as well as with cumulative water application depth.
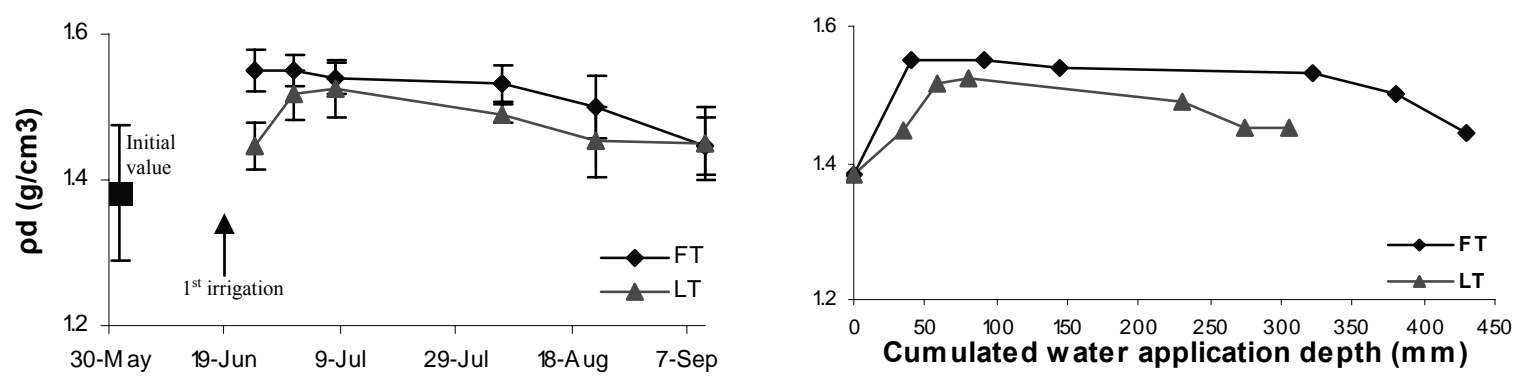

5

6 Fig. 5 Evolution of dry bulk density, $\rho_{d}$ (arithmetic mean with standard deviation) for both treatments

7 with time as well as with cumulative water application depth. 
Table 1. Statistical parameters of dry bulk density and hydraulic properties for both treatments FT and

\begin{tabular}{|c|c|c|c|c|c|c|c|c|c|}
\hline Date & Treatment FT & $\underset{g c m^{-3}}{\rho d}$ & $\begin{array}{c}\theta s \\
m^{3} m^{-3}\end{array}$ & $n$ & $m$ & $\eta$ & $\begin{array}{c}K s \\
m m s^{-1}\end{array}$ & $\begin{array}{c}\alpha h \\
m m\end{array}$ & $\underset{m m}{\xi m}$ \\
\hline \multirow[t]{2}{*}{$I^{s t}$ June } & $\operatorname{Mean}(8)^{+}$ & 1.383 & 0.478 & 2.201 & 0.0915 & 12.93 & $8.49 \mathrm{E}-03 *$ & $53.9^{*}$ & $0.276^{*}$ \\
\hline & $\mathrm{CV} \%$ & 6.7 & 7.3 & & & & 20.6 & 18.0 & 16.3 \\
\hline \multirow[t]{2}{*}{$24^{\text {th }}$ June } & $\operatorname{Mean}(8)^{+}$ & 1.550 & 0.415 & 2.210 & 0.0951 & 12.52 & $2.79 \mathrm{E}-03 *$ & $81.2 *$ & $0.183 *$ \\
\hline & $\mathrm{CV} \%$ & 1.9 & 2.4 & & & & 33.3 & 15.0 & 16.4 \\
\hline \multirow[t]{2}{*}{$1^{s t} \mathrm{July}$} & $\operatorname{Mean}(6)^{+}$ & 1.550 & 0.415 & 2.210 & 0.0951 & 12.52 & $1.79 \mathrm{E}-03 *$ & $111.1^{*}$ & $0.134^{*}$ \\
\hline & $C V \%$ & 1.3 & 1.9 & & & & 31.4 & 21.2 & 24.2 \\
\hline \multirow[t]{2}{*}{$8^{\text {th }} \mathrm{July}$} & $\operatorname{Mean}(8)^{+}$ & 1.540 & 0.419 & 2.210 & 0.0948 & 12.54 & $1.60 \mathrm{E}-03 *$ & $121.0^{*}$ & $0.123^{*}$ \\
\hline & $\mathrm{CV} \%$ & 1.4 & 1.9 & & & & 31.7 & 18.1 & 15.6 \\
\hline \multirow[t]{2}{*}{$\sigma^{\text {th }}$ August } & $\operatorname{Mean}(6)^{+}$ & 1.532 & 0.422 & 2.210 & 0.0946 & 12.57 & $2.76 \mathrm{E}-03 *$ & $85.6^{*}$ & $0.174 *$ \\
\hline & $\mathrm{CV} \%$ & 1.6 & 2.0 & & & & 31.8 & 14.1 & 13.8 \\
\hline \multirow[t]{2}{*}{$22^{\text {th }}$ August } & $\operatorname{Mean}(6)^{+}$ & 1.500 & 0.434 & 2.210 & 0.0939 & 12.65 & $4.17 \mathrm{E}-03 *$ & $73.5^{*}$ & $0.202 *$ \\
\hline & $\mathrm{CV} \%$ & 2.9 & 4.0 & & & & 9.1 & 15.6 & 14.8 \\
\hline \multirow[t]{2}{*}{$10^{\text {th }}$ September } & $\operatorname{Mean}(8)^{+}$ & 1.445 & 0.455 & 2.204 & 0.0926 & 12.80 & $5.26 \mathrm{E}-03 *$ & $72.2 *$ & $0.206^{*}$ \\
\hline & $\mathrm{CV} \%$ & 2.7 & 3.3 & & & & 26.1 & 19.8 & 19.5 \\
\hline Date & Treatment $L T$ & $\underset{g c m^{-3}}{\rho d}$ & $\begin{array}{c}\theta s \\
m^{3} m^{-3}\end{array}$ & $n$ & $m$ & $\eta$ & $\begin{array}{c}K s \\
m m s^{-1}\end{array}$ & $\begin{array}{c}\alpha h \\
m m\end{array}$ & $\begin{array}{c}\xi m \\
m m\end{array}$ \\
\hline \multirow[t]{2}{*}{$I^{s t}$ June } & $\operatorname{Mean}(8)^{+}$ & 1.383 & 0.478 & 2.201 & 0.0915 & 12.93 & $8.49 \mathrm{E}-03 *$ & $53.9^{*}$ & $0.276^{*}$ \\
\hline & $C V \%$ & 6.7 & 7.3 & & & & 20.6 & 18.0 & 16.3 \\
\hline \multirow[t]{2}{*}{$24^{\text {th }}$ June } & $\operatorname{Mean}(8)^{+}$ & 1.446 & 0.454 & 2.206 & 0.0933 & 12.72 & $3.25 \mathrm{E}-03 *$ & $70.5^{*}$ & $0.211^{*}$ \\
\hline & $\mathrm{CV} \%$ & 2.3 & 2.7 & & & & 21.1 & 8.7 & 8.4 \\
\hline \multirow[t]{2}{*}{$1^{s t} J u l y$} & $\operatorname{Mean}(6)^{+}$ & 1.517 & 0.428 & 2.210 & 0.0950 & 12.53 & $3.35 \mathrm{E}-03 *$ & $88.4^{*}$ & $0.168^{*}$ \\
\hline & CV \% & 2.2 & 3.0 & & & & 11.6 & 7.7 & 7.6 \\
\hline \multirow[t]{2}{*}{$8^{\text {th }} \mathrm{July}$} & $\operatorname{Mean}(8)^{+}$ & 1.525 & 0.425 & 2.210 & 0.0952 & 12.51 & $4.07 \mathrm{E}-03 *$ & $107.1^{*}$ & $0.139 *$ \\
\hline & $\mathrm{CV} \%$ & 2.6 & 3.3 & & & & 23.5 & 6.0 & 5.8 \\
\hline \multirow[t]{2}{*}{$6^{\text {th }}$ August } & $\operatorname{Mean}(6)^{+}$ & 1.490 & 0.438 & 2.210 & 0.0943 & 12.60 & $6.15 \mathrm{E}-03 *$ & $79.7 *$ & $0.187 *$ \\
\hline & $\mathrm{CV} \%$ & 0.9 & 1.0 & & & & 16.4 & 11.1 & 11.0 \\
\hline \multirow[t]{2}{*}{$22^{\text {th }}$ August } & $\operatorname{Mean}(6)^{+}$ & 1.452 & 0.452 & 2.206 & 0.0934 & 12.70 & $6.25 \mathrm{E}-03 *$ & $74.3^{*}$ & $0.200^{*}$ \\
\hline & $C V \%$ & 3.2 & 3.7 & & & & 18.6 & 22.3 & 22.2 \\
\hline \multirow[t]{2}{*}{$10^{\text {th }}$ September } & $\operatorname{Mean}(6)^{+}$ & 1.451 & 0.452 & 2.206 & 0.0934 & 12.70 & $7.72 \mathrm{E}-03 *$ & $69.7^{*}$ & $0.214^{*}$ \\
\hline & $C V \%$ & 3.4 & 4.2 & & & & 19.1 & 11.4 & 11.6 \\
\hline
\end{tabular}


1 Table 2. Comparison of soil hydraulic properties in each treatment i.e., Full Treatment and Limited 2 Treatment

\begin{tabular}{|c|c|c|c|c|c|c|}
\hline \multirow{2}{*}{ Date } & \multicolumn{3}{|c|}{ Full treatment } & \multicolumn{3}{|c|}{ Limited treatment } \\
\hline & $\begin{array}{c}K s \\
m m s^{-1}\end{array}$ & $\begin{array}{c}\alpha h \\
m m\end{array}$ & $\begin{array}{l}\xi m \\
m m\end{array}$ & $\begin{array}{c}K s \\
m m s^{-1}\end{array}$ & $\begin{array}{c}\alpha h \\
m m\end{array}$ & $\begin{array}{c}\xi m \\
m m\end{array}$ \\
\hline $1^{\text {st }}$ June & $8.49 \mathrm{E}-03 *$ & 53.9 & 0.276 & 8.49E-03 & 53.9 & 0.276 \\
\hline $24^{\text {th }}$ June & $2.79 \mathrm{E}-03$ & 81.2 & 0.183 & $3.25 \mathrm{E}-03$ & 70.4 & 0.211 \\
\hline Difference & $5.70 \mathrm{E}-03^{+}$ & $-27.3^{+}$ & $0.093^{+}$ & $5.24 \mathrm{E}-03^{+}$ & $-16.5^{+}$ & $0.065^{+}$ \\
\hline $24^{\text {th }}$ June & $2.79 \mathrm{E}-03$ & 81.2 & 0.183 & $3.25 \mathrm{E}-03$ & 70.4 & 0.211 \\
\hline $8^{\text {th }} J u l y$ & $1.60 \mathrm{E}-03$ & 121.0 & 0.123 & 4.07E-03 & 107.1 & 0.139 \\
\hline Difference & $1.19 \mathrm{E}-03^{+}$ & $-39.8^{+}$ & $0.060^{+}$ & $-8.21 \mathrm{E}-04 \mathrm{NS}$ & $-36.6^{+}$ & $0.072^{+}$ \\
\hline $8^{\text {th }}$ July & $1.60 \mathrm{E}-03$ & 121.0 & 0.123 & 4.07E-03 & 107.1 & 0.139 \\
\hline $10^{\text {th }}$ September & $5.26 \mathrm{E}-03$ & 72.2 & 0.206 & 7.72E-03 & 69.7 & 0.214 \\
\hline Difference & $-3.66 \mathrm{E}-03^{+}$ & $48.7^{+}$ & $-0.083^{+}$ & $-3.65 \mathrm{E}-03^{+}$ & $37.4^{+}$ & $-0.075^{+}$ \\
\hline$I^{\text {st }}$ June & $8.49 \mathrm{E}-03$ & 53.9 & 0.276 & $8.49 \mathrm{E}-03$ & 53.9 & 0.276 \\
\hline $10^{\text {th }}$ September & $5.26 \mathrm{E}-03$ & 72.2 & 0.206 & $7.72 \mathrm{E}-03$ & 69.7 & 0.214 \\
\hline Difference & $3.24 \mathrm{E}-03^{+}$ & $-18.3^{+}$ & $0.070^{+}$ & $7.73 \mathrm{E}-04^{+}$ & $-15.7^{+}$ & $0.062^{+}$ \\
\hline
\end{tabular}

3 *Geometric mean value. Difference = Date 1 - Date 2

$4+$ Significance at 0.05 probability level.

$5 \quad$ NS indicates no significant difference.

$6 \quad 1^{\text {st }}$ June: before irrigation started.

$724^{\text {th }}$ June: some days after the $1^{\text {st }}$ irrigation event.

$8 \quad \boldsymbol{8}^{\text {th }}$ July: rooting system approximately reaches its maximal value

$910^{\text {th }}$ September: just prior to harvest.

10

11 
1 Table 3. Comparison of soil hydraulic properties between Full Treatment and Limited Treatment.

\begin{tabular}{r|c|ccc}
\hline \multicolumn{1}{c|}{ Date } & Treatment & $\begin{array}{c}\boldsymbol{K} \boldsymbol{s} \\
\boldsymbol{m m} \boldsymbol{~}^{-1}\end{array}$ & $\begin{array}{c}\boldsymbol{\alpha} \boldsymbol{h} \\
\mathbf{m m}\end{array}$ & $\begin{array}{c}\boldsymbol{\xi} \boldsymbol{m} \\
\mathbf{m m}\end{array}$ \\
\hline \multirow{2}{*}{$\boldsymbol{4}^{\text {th }}$ June } & $\boldsymbol{F T}$ & $2.79 \mathrm{E}-03^{*}$ & 81.2 & 0.183 \\
& $\boldsymbol{L T}$ & $3.25 \mathrm{E}-03$ & 70.4 & 0.211 \\
& Difference & $-4.61 \mathrm{E}-04 \mathrm{NS}$ & $10.7 \mathrm{NS}$ & $-0.028 \mathrm{NS}$ \\
\hline $\boldsymbol{8}^{\text {th }}$ July & $\boldsymbol{F T}$ & $1.60 \mathrm{E}-03$ & 121.0 & 0.123 \\
& $\boldsymbol{L T}$ & $4.07 \mathrm{E}-03$ & 107.1 & 0.139 \\
& Difference & $-2.47 \mathrm{E}-03^{+}$ & $13.9 \mathrm{NS}$ & $-0.016 \mathrm{NS}$ \\
\hline $\mathbf{1 0}^{\text {th }}$ September & $\boldsymbol{F T}$ & $5.03 \mathrm{E}-03$ & 72.2 & 0.206 \\
& $\boldsymbol{L T}$ & $7.72 \mathrm{E}-03$ & 69.7 & 0.214 \\
& Difference & $-2.69 \mathrm{E}-03^{+}$ & $2.6 \mathrm{NS}$ & $-0.008 \mathrm{NS}$ \\
\hline
\end{tabular}

$2 *$ Geometric mean value. Difference = Date $1-$ Date 2

$3+$ Significance at 0.05 probability level.

$4 \quad$ NS indicates no significant difference. 
1 Table 4. Comparison of wetting pattern dimensions between different dates for input parameters: $q=2$ $2 \mathrm{Lh}^{-1}$ as emitter flow rate, and the difference $(\Delta \theta=0.2)$ between initial water content and mean value of 3 water content of the wetted soil volume supposed uniform

4

\begin{tabular}{r|cccc|cccc}
\cline { 2 - 7 } & \multicolumn{3}{|c|}{$\boldsymbol{t}=\mathbf{1 2 h} \boldsymbol{h}$} & \multicolumn{3}{c}{$\boldsymbol{t}=\mathbf{2 4 h \boldsymbol { h }}$} \\
\hline The radius of the wetted soil volume, $\boldsymbol{r}(\mathbf{c m})=$ & 22.4 & 25.6 & 28.5 & 25.85 & 30.02 & 33.85 \\
The depth of the wetted soil volume, $\boldsymbol{z}(\mathbf{c m})=$ & 67.3 & 58.8 & 52.7 & 92.5 & 79.73 & 70.51 \\
Applied water volume (liter) $=\boldsymbol{q t}$ & 24 & 24 & 24 & 48 & 48 & 48 \\
Volume of the wetted soil (litre $)=\boldsymbol{q t} / \boldsymbol{\Delta \theta}$ & 120 & 120 & 120 & 240 & 240 & 240 \\
\hline
\end{tabular}

$5 \quad 1^{\text {st }}$ June: before irrigation started.

$624^{\text {th }}$ June: some days after the $1^{\text {st }}$ irrigation event.

$7 \quad \delta^{\text {th }} \mathrm{July}$ : rooting system approximately reaches its maximal value

8 